\title{
Faktor-Faktor Yang Mempengaruhi Prestasi Kerja Karyawan Pada PT. Excelcomindo Engineering IndonesiaSumatera
}

\author{
Muhammad Kurniawan \\ Manajemen, Fakultas Ekonomi Universitas PGRI Palembang Palembang \\ email: iwanusman220506@gmail.com
}

\begin{abstract}
ABSTRAK
Rumusan masalah dalam penelitian ini adalah apakah faktor-faktor yang mempengaruhi prestasi kerja karyawan pada PT. Excelcomindo Engineering Indonesia Sumatera. Metode yang digunakan dalam penelitian ini adalah metode Diskriptif Kualitatif Dari hasil penelitian ini terdapat sistem penempatan karyawan yang kurang baik seperti masih adanya penempatan karyawan yang tidak sesuai dengan riwayat pendidikan, dalam hal ini tamatan SMA ditempatkan dibagian lapangan, sedangkan tamatan STM ditempatkan dibagian administrasi. Serta lingkungan kerja yang kurang mendukung karena masih kurangnya sarana dan prasarana penunjang operasional perusahaan seperti bangunan atau gedung, ruangan yang kurang memadai, kamar kecil serta alat penunjang lainnya diantaranya pendingin udara (AC), Komputer dan alat-alat perkantoran lainnya. Disarankan sebaiknya perusahaan harus memperbaiki lagi sistem penempatan tenaga kerja, agar perusahaan mengevaluasi kembali sebelum menempatkan karyawan pada suatu jabatan, berdasarkan kemampuan dan keterampilan yang dimiliki oleh karyawan tersebut sehingga penempatan itu dapat tepat sasaran. Serta sebaiknya perusahaan memperhatikan, bahkan menambah sarana dan prasarana pendukung yang jauh lebih baik dari sebelumnya dalam proses peningkatan prestasi kerja karyawan.
\end{abstract}

Kata Kunci : Lingkungan kerja, Kompensasi, dan Prestasi Kerja Karyawan

\section{A. Latar Belakang}

Pada dasarnya manajemen suatu perusahaan memiliki suatu tujuan tertentu, berhasil atau tidaknya manajemen dapat dilihat dari tercapai tidaknya tujuan yang telah ditetapkan tersebut, dan dalam usaha untuk mencapai tujuan perusahaan tidak dapat melakukan pekerjaan sendiri melainkan memerlukan unsur-unsur manajemen lain yang mendukung dalam melaksanakan oprasional sehari-hari. Pada umumnya perusahaan bertujuan untuk mendapatkan hasil yang tinggi dengan keuntungan yang semaksimal mungkin, untuk mewujudkan tujuan tersebut bukanlah pekerjaan yang mudah, banyak hal yang harus direncanakan sampai tujuan akhir tercapai. Menyadari hal tersebut, maka dalam pengolahannya diperlukannya sumber daya manusia yang bertanggung jawab terhadap sukses tidaknya kegiatan perusahaan.

Faktor terpenting dari setiap manajemen dalam usahanya mencapai tujuan yang telah ditetapkan terlebih dahulu adalah unsur manusia, karena untuk melakukan berbagai aktivitas manajemen yang dilaksanakan oleh para manajer diperlukan manusia, tanpa adanya unsur manusia manajemen tidak akan mencapai tujuannya,oleh karena itu unsur manusia memegang peranan khusus dalam kegiatan atau aktivitas perusahaan untuk dapat berproduksi dan berprestasi.

Manusia sebagai faktor produksi merupakan makhluk hidup yang mempunyai akal, perasaan dan tujuan pribadi yang mana para pelakunya harus diberikan perhatian yang utama, oleh karena itu bagi pemimpin yang bijak harus memperhatikan setiap karyawannya dengan cara 
memeberikan gaji yang setimpal dengan posisi jabatan yang diembannya. Pemberian gaji yang sesuai dapat memotivasi setiap karyawannya dalam menyelesaikan tugasnya dengan baik, dan ada baiknya juga para pemimpin memberikan bonus kepada karyawan baik dalam berupa materi ataupun promosi jabatan yang lebih baik sehingga setiap karyawan bisa memacu kembali semangat kerjanya.

Adapun yang harus diperhatikan oleh seorang pemimpin dalam meningkatkan prestasi kerja karyawan yaitu faktor eksternal dan internal. Faktor Eksternal yang meliputi teknologi, peralatan dan metode kerja, dalam faktor ini pemimpin cukup memberikan hal-hal yang baru mengenai teknologi, peralatan dan metode kerja. Sehingga karyawan dapat merasakan hal yang baru pula misalnya dalam hal teknologi, yang tadinya hanya menggunakan mesin tik maka sekarang menggunakan komputer, begitu pula dengan peralatan dan teknologi yang tadinya masih menggunakan peralatan kerja yang tradisional atau sederhana sekarang menggunakan peralatan yang canggih.

Sedangkan untuk Faktor Internal pemimpin hanya memberikan motivasi dan sistem manajemen yang baru antara lain skill dan training. Dalam hal ini pemberian motivasi adalah memberi dorongan kepada karyawannya sehingga dengan dorongan tersebut karyawan dapat mengerjakan tugastugas yang diberikan dengan baik. Sedangkan untuk pemberian sistem manajemen pemimpin cukup menggantikan sistem manajemen yang lama perusahaan dengan yang baru, sedangkan untuk skil dan training pemimpin harus memberikan pelatihan-pelatihan khusus sehingga skill karyawan dapat bertambah dari sebelumnya dan pemimpin juga harus memberikan training- training kepada karyawan sesuai dengan instansi yang ditunjuk.

Ada pun masalah yang diangkat oleh penulis dalam penelitian ini adalah mengenai sistem penempatan karyawan yang kurang baik dan lingkungan kerja yang kurang mendukung, misalkan bagian untuk lapangan rata-rata ditempatkan Iulusan SMA, sedangkan untuk bagian perkantoran rata-rata lulusan STM. Hal ini menunjukan bahwa sistim yang digunakan oleh perusahaan dalam penempatan karyawan kurang baik, sistem penempatan yang kurang baik dapat membuat perusahaan mengalami kemunduran

Begitu juga lingkungan kerja yang kurang mendukung dapat membuat gairah kerja karyawan menjadi menurun, hal ini juga bisa disebabkan oleh sarana dan prasarana yang diberikan, misalkan alat pendingin udara (AC) dalam hal ini karyawan dapat menjalankan aktivitas kerjanya tanpa merasa kepanasan. Untuk itu pemberian motivasi kepada seluruh karyawan yang dilakukan sedemikian rupa untuk mendapatkan semangat kerja dan moral kerja yang tinggi dari karyawan yang mengarah pada prestasi kerja atau mutu kerja untuk mencapai hasil yang sempurna.

Selain itu juga pemberian kompensasi memberikan pengaruh yang sangat besar terhadap prestasi kerja karyawan, oleh karena itu perusahaan harus memperhatikan kembali tentang pemberian kompensasi sesuai dengan beban kerja yang diberikan perusahan kepada karyawan sehingga ada keseimbangan antara perusahaan dan karyawan, sehingga terciptanya keselarasan antara keduanya sehingga terjadi peningkatan prestasi kerja yang diharafkan. 


\section{B. Rumusan Masalah}

Dari uraian latar belakang diatas penulis menemukan masalah yang dialami oleh PT. Exelcomindo Engineering Indonesia Sumateraadalah "Apakah faktor-faktor yang mempengaruhi prestasi kerja karyawan pada PT. Exelcomindo Engineering Indonesia Sumatera.?"

\section{Landasan Teori}

\section{$>$ Pengertian Prestasi Kerja}

Menurut Mangkunegara (2005 : 67) prestasi kerja adalah hasil kerja secara kualitas dan kuantitas yang dicapai oleh seorang karyawan / pegawai dalam melaksanakan tugas sesuai dengan tanggung jawab yang diberikan padanya.

Menurut Liang Gie (2002:191) prestasi kerja adalah pemberian dorongan terhadap tindakan - tindakan yang dijalankan oleh bawahan untuk menggiatkan orang-orang atau karyawan agar mereka bersemangat dan dapat mencapai hasil sebagaimana yang dikehendaki oleh orang-orang tersebut.

Sedangkan Menurut Siswanto (2003:195) prestasi kerja adalah hasil kerja yang dicapai oleh seorang tenaga kerja dalam melaksanakan tugas dan pekerjaan yang dibebankan kepadanya. Pada umumnya prestasi kerja seseorang karyawan dipengaruhi oleh kecakapan, keterampilan, pengalaman dan kesungguhan karyawan yang bersangkutan.

Dari definisi beberapa ahli maka penulis menyimpulkan bahwa prestasi kerja adalah : hasil kerja dari setiap karyawan yang dinilai oleh perusahaan atau orang yang berwewenag, sebagai pedoman atau acuan bagi perusahaan apakah karyawan tersebut berkwalitas atau tidak serta berhak atau tidak untuk memperoleh kompensasi atau peningkatan jabatan yang lebih baik.

\section{Penilaian Prestasi Kerja}

Penilaian prestasi kerja, menurut Handoko (2001 : 135) adalah proses melalui mana organisasi-organisasi mengevaluasi atau menilai prestasi kerja karyawan. Kegiatan ini dapat memperbaiki keputusan-keputusan personalia dan memberikan umpan balik kepada perusahaan.

Menurut Hasibuan (2017 : 97) penilaian prestasi kerja adalah menilai rasio hasil kerja nyata dengan standar kualitas maupun kuantitas yang dihasilkan setiap karyawan.

Penilaian prestasi kerja (perforamance appraisal) dalam rangka pengembangan sumber daya manusia adalah sangat penting artinya, hal ini mengingat bahwa dalam kegiatan organisasi setiap orang atau sumber daya manusia dalam organisasi ingin mendapatkan penghargaan dan perlakuan yang adil dari pimpinan organisasi yang bersangkutan.

Dalam kehidupan suatu organisasi ada beberapa asumsi tentang prilaku manusia sebagai sumber daya manusia yang mendasari pentingnya penilaian prestasi kerja. Asumsi-asumsi tersebut adalah sebagai berikut :

a. Setiap orang ingin memiliki peluang untuk mengembangkan kemampuan kerjanya sampai tingkat maksimal.

b. Setiap orang ingin mendapatkan penghargaan apabila ia dinilai melaksanakan tugas dengan baik

c. Setiap orang ingin mengetahui secara pasti tangga karier yang dinaikinya apabila dapat melaksanakan tugasnya dengan baik

d. Setiap orang ingin mendapatkan perlakuan yang objektif dan penilaian atas prestasi kerjanya.

e. Setiap orang bersedia menerima tanggung jawab yang lebih besar 
f. Setiap orang pada umumnya tidak hanya melakukan kegiatan yang rutin tanpa informasi.

Berdasarkan asumsi-asumsi tersebut diatas penulis menarik kesimpulan bahwa penilaian pretasi kerja adalah penting bagi setiap organisasi dalam rangka pengembangan sumber daya manusia. Kegiatan ini dapat memperbaiki keputusan manajer dan memberikan umpan balik kepada para karyawan tentang kegiatan mereka.

\section{$>\quad$ Manfaat Penilaian Prestasi Kerja}

Menurut Veithzal Rivai (2009:315) menyebut manfaat penilaian prestasi kerja sebagai berikut:

1. Perbaikan prestasi kerja

2. Penyesuaian kompensasi

3. Keputusan penempatan

4. Kebutuhan latihan dan pengembangan

5. Perencanaan dan pengembangan karir

6. Penyimpanan proses staffing

7. Ketidakakuratan informasional

8. Kesalahan-kesalahan desain pekerjaan

9. Kesempatan kerja yang adil

10. Tantangan-tantangan eksternal

Secara rinci manfaat penilaian prestasi kerja dalam suatu organisasi antara lain sebagai berikut :

a. Penilaian prestasi kerja

Dengan adanya penilaian, baik manajer maupun karyawan memperoleh umpan balik dan mereka dapat memperbaiki pekerjaan mereka.

b. Kesempatan kerja yang adil

Dengan adanya penilaian prestasi kerja yang akurat akan menjamin setiap karyawan akan memperoleh kesempatan menempati posisi pekerjaan sesuai dengan kemampuan mereka.

c. Kebutuhan-kebutuhan pelatihan pengembangan

Melalui penilaian prestasi kerja akan dideteksi karyawankaryawan yang kemampuannya rendah, dan kemudian memungkinkan adanya program pelatihan untuk meningkatkan kemampuan mereka.

d. Penyesuaian kompensasi

Penilaian prestasi kerja dapat membantu para manajer untuk mengambil keputusan dalam menentukan perbaikan pemberian kompensasi, gaji, bonus dan sebagainya.

e. Keputusan-keputusan promosi dan demosi

Hasil penilaian prestasi kerja terhadap karyawan dapat digunakan untuk mengambil keputusan untuk mempromosikan karyawan yang berprestasi baik, dan demosi untuk karyawan yang berprestasi buruk.

f. Kesalahan-kesalahan desain pekerjaan

Hasil penilaian prestasi kerja dapat digunakan untuk menilai desain kerja. Artinya hasil penilaian prestasi kerja ini dapat membantu mendiagnosis kesalahan-kesalahan desain kerja.

g. Penyimpangan-penyimpangan proses rekruitmen dan seleksi

Penilaian prestasi kerja dapat digunakan untuk menilai proses rekrutmen dan seleksi karyawan yang telah lalu. Prestasi kerja yang sangat rendah bagi karyawan baru adalah mencerminkan adanya penyimpangan-penyimpangan proses rekruitmen dan seleksi. 


\section{Unsur-Unsur Yang Perlu Diadakan Dalam Penilaian Prestasi Kerja}

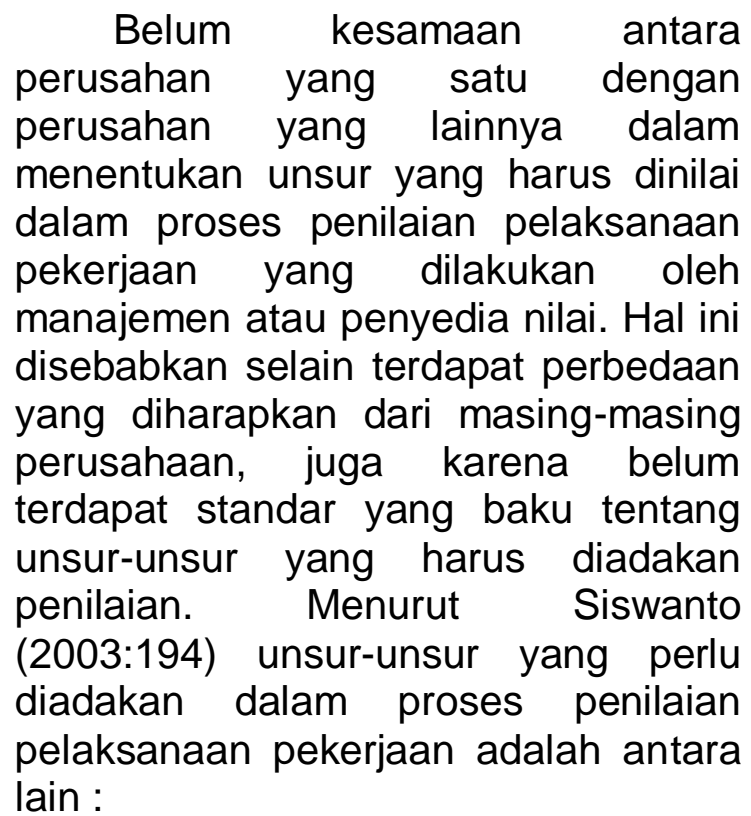

\section{Kesetiaan}

Kesetiaan yang dimaksut adalah tekat dan kesanggupan menaati, melaksanakan, dan mengamalkan sesuatu yang ditaati dengan penuh kesadaran dan penuh tanggung jawab. Takat dan kesanggupan tersebut harus dibuktikan dengan sikap dan tingkah laku tenaga kerja yang bersangkutan dalam kegiatan sehari-hari serta dalam melaksanakan tugas dan pekerjaan yang dibebankan kepadanya. Kesetiaan tenaga kerja terhadap perusahaan sangat berhubungan dengan pengabdiaannya. Pengabdian yang dimaksud adalah sumbangan pikiran, dan tenaga yang ikhlas dengan mengutamakan kepentingan publik diatas kepentingan pribadi.

\section{Prestasi Kerja}

Prestasi kerja adalah hasil kerja yang dicapai oleh seorang tenaga kerja dalam melaksanakan tugas dan pekerjaan yang dibebankan kepadanya. Pada umumnya prestasi kerja seorang tenaga kerja antara lain dipengaruhi oleh kecakapan, keterampilan, pengalaman dan kesungguhan tenaga kerja yang bersangkutan.

\section{Tanggung Jawab}

Tanggung jawab adalah kesanggupan seorang tenaga kerja dalam menyelesaikan tugas yang diserahkan kepadanya dengan sebaikbaiknya dan tepat waktu dan berani memikul resiko atas keputusan yang telah diambilnya atau tindakan yang dilakukannya.

\section{Ketaatan}

Ketaatan adalah kesanggupan tenaga kerja untuk menaati segala ketentuan, peraturan perundangundangan dan peraturan kedinasan yang berlaku, menaati perintah kedinasan yang diberikan oleh atasan yang berwewenang, serta kesanggupan untuk tidak melanggar larangan yang telah ditentukan oleh perusahaan maupun pemerintah, baik secara tertulis maupun tidak tertulis.

\section{Kejujuran}

Ketulusan hati seorang tenaga kerja dalam melaksanakan tugas dan pekerjaan serta kemampuan untuk tidak menyalahgunakan wewenang yang telah diberikan kepadanya.

6. Kerja Sama

Kemampuan seorang tenaga kerja bersama-sama dengan orang lain dalam menyelesaikan suatu tugas dan pekerjaan yang telah ditentukan, sehingga mencapai daya guna dan hasil guna yang sebesar-besarnya.

\section{Prakarsa}

Prakarsa adalah kemampuan seorang tenaga kerja untuk mengambil keputusan, langkah-langkah atau melaksanakan sesuatu tindakan yang diperlukan dalam melaksanakan tugas pokok tanpa menunggu perintah dan bimbingan dari manajemen lain.

8. Kepemimpinan 
Kepemimpinan

adalah

kemampuan yang dimiliki oleh seorang tenaga kerja untuk meyakinkan orang lain (tenaga kerja lain) sehingga dapat dikerahkan secara maksimal untuk melaksanakan tugas pokok. Penilaian unsur kepemimpinan bagi tenaga kerja sebenarnya khusus diperuntukan bagi tenaga kerja yang mempunyai jabatan dalam perusahaan, baik top management, middle management, maupun Iwer management.

\section{$>\quad$ Metode-Metode Penilaian Prestasi Kerja}

Menurut Husein Umar (2001:15) metode penilaian prestasi kerja ada dua yaitu :

\section{Metode Penilaian Berorientasi Masa Lalu \\ Metode ini mempunyai kelebihan} dalam hal perlakuaan terhadap prestasikerja yang telah terjadi yang dapat diukur, sehingga paling tidak karyawan mempunyai umpan balik mengenai usaha mereka.

Teknik penilaian ini mencakup antara lain :

a. Rating Scale

Dalam hal ini penilaian subjektif terhadap prestasi kerja karyawan dengan skala tertentu dari yang terendah sampai dengan yang tinggi

b. Cheklist

Dalam penilaian ini hanya memiliki pernyataan-pernyataan yang sudah tersedia, yang menggambarkan prestasi kerja dan karakter-karakteristik karyawan (yang dinilai).

c. Peristiwa Kritis

Metode penilaian ini didasarkan pada catatan-catatan dari pimpinan atau penilaian karyawan yang bersangkutan.

d. Metode Peninjauan Lapangan

Hal ini dapat dilakukan dengan cara supervisi yaitu pimpinan dapat melakukan penilaian terhadap kerja para karyawan, sedangkan secara sengaja dan terencana yaitu para penilai mendatangi tempat kerja para karyawan untuk melakukan penilaian prestasi yang bersangkutan.

e. Tes Prestasi Kerja

Metode penilaian ini dilakukan dengan mengadakan tes tertulis kepada karyawan yang akan dinilai.

\section{Metode Penilaian Berorientasi Masa Depan}

Metode ini memusatkan prestasi kerja diwaktu yang akan datang melalui penilaiaan potensi karyawan atau melalui penetapan sasaran prestasi di masa datang, teknik yang digunakan adalah :

a. Penilaian diri (Self Appraisals)

Metode penilaian ini menekankan bahwa penilaian prestasi kerja karyawan dinilai itu sendiri. Tujuannya yaitu untuk mengembangkan diri karyawan dalam rangka pengembangan organisasi.

b. Penilaian psikologis (Psychological Appraisals)

Metode penilaian dilakukan dengan mengadakan wawancara mendalam, diskusi, atau tes-tes psikologis terhadap karyawan yang akan dinilai.

\section{$>\quad$ Tujuan Penilaian Prestasi Kerja}

Menurut Henry Simamora (2001:425) mengemukakan tujuan yang ingin dicapai dalam penilaian prestasi kerja :

1. Tujuan Evaluasi

Untuk menilai kinerja masa lalu sebagai basi untuk pelaksanaan keputusan-keputusan personalia

2. Tujuan Pengembangan

a. Untuk memotivasi dan mengarahkan kinerja individu dan upaya-upaya karir 
b. Mengukuhkan prestasi kerja

c. Meningkatkan prestasi kerja

d. Menentukan tujuan progresi karir

f. Menentukan kebutuhankebutuhan pelatihan

\section{Faktor-faktor mempengaruhi prestasi kerja.}

Menurut Timpe dalam Mangkunegara (2006:15), faktor-faktor prestasi kerja terdiri dari faktor internal dan faktor eksternal. Faktor Internal (disposisional) yaitu faktor yang dihubungkan dengan sifat-sifat seseorang. Misalnya, prestasi kerja seseorang baik disebabkan karena mempunyai kemampuan tinggi dan seseorang itu tipe pekerja keras, sedangkan seseorang mempunyai prestasi kerja buruk disebabkan orang tersebut mempunyai kemampuan rendah dan orang tersebut tidak memiliki upaya-upaya untuk memperbaiki kemampuannya. Faktor eksternal yaitu faktor-faktor yang mempengaruhi prestasi kerja seseorang yang berasal dari lingkungan. Seperti perilaku, sikap, dan tindakan-tindakan rekan kerja, bawahan atau pimpinan, fasilitas kerja, dan iklim organisasi.

\section{Populasi dan Sampel \\ 1. Populasi Penelitian Menurut}

Sanusi(2014:87),Populasi adalah Seluruh kumpulan elemen yang menunjukkan ciri-ciri tertentu yang dapat digunakan untuk membuat kesimpulan.Jadi populasi dalam penelitian ini adalah semua karyawan yang ada dibidang Sumber Daya Manusia dan Administrasi pada PT. Exelcomindo Engineering Indonesia Sumaterayang berjumlah 100 orang.

2. Sampel Penelitian

Menurut Sanusi (2014:88), Sampel yang baik adalah sampel yang dapat mewakili karakteristik populasinya yang ditunjukkan oleh tingkat akurasi dan presisinya. SedangkanMenurutArikunto (2013 : 108) apabila subjek kurang dari 100 , lebih baik diambil semua sehingga penelitiannya merupakan penelitian populasi, sedangkan jika jumlah subjek lebih dari 100 , dapat diambil $10-15 \%$ atau $20-25 \%$ bahkan lebih tergantung setidak-tidaknya dari kemampuan peneliti dilihat dari segi waktu dan lamanya, sedikit luasnya wilayah pengamatan dari setiap subjek karena hal ini menyangkut banyak sedikitnya data.

Berdasarkan pendapat tersebut diatas, maka penulis mengambil $50 \%$ dari jumlah karyawan yang dijadikan sebagai populasi sebanyak100 orang, sehingga jumlah sample penelitian ini sebanyak50 orang.

\section{E. Teknik Pengumpulan Data}

Data yang digunakan dalam penulisan skripsi ini adalah :

1. Data Primer

Data yang langsung dikumpulkan dari objek yang diteliti, dalam hal ini PT. Exelcomindo Engineering Indonesia Sumatera. Data tersebut penulis kumpulkan dengan teknik sebagai berikut :

a) Observasi

Pengamatan langsung ke objek penelitian dengan mencatat secara sistematis data yang dikumpulkan.

b) Interview

Mengadakan wawancara dengan pimpinan atau karyawan PT. Exelcomindo Engineering Indonesia Sumatera. yang dianggap dapat memberikan informasi yang dibutuhkan mengenai prestasi kerja.

2. Data Sekunder

Mengumpulkan data dengan mempelajari masalah yang berhubungan dengan objek yang diteliti melalui buku-buku pedoman, 
literatur yang oleh para ahli berhubungan dengan masalah yang sedang dianalisa.

\section{F. Teknik Analisis Data}

Penulis dalam analisa data menggunakan metode penelitian Deskriptif Kualitatif, dengan cara mengumpulkan data, menyusun data, menyajikan data, menginterprestasikan data serta mengambil suatu kesimpulan.

\section{G. Hasil Penelitian}

\section{> Sistem Penempatan Karyawan}

Penempatan karyawan pada PT. Exelcomindo Engineering Indonesia Sumateraselama ini terdapat kesalahan penempatan, dimana masih banyaknya posisi suatu jabatan ditempati oleh orang yang bukan seharusnya menduduki posisi tersebut. Sebagai contoh bagian administrasi diduduki oleh tamatan STM sedangkan bagian lapangan diduduki oleh tamatan SMA. Padahal seharusnya penempatan karyawan harus sesuai dengan tempat dan kedudukannya, penuh dedikasi serta loyalitas yang tinggi guna menduduki suatu jabatan tertentu. Menurut Sunyoto (2015:124)Konsep penempatan mencakup sebagai berikut :

1. Promosi.

Jika seorang karyawan atau pegawai dipindahkan dari satu pekerjaan ke pekerjaan lain yang tanggung jawabnya lebih besar, tingkatan hierarki jabatan lebih tinggi dan penghasilannya pun lebih besar pula. Setiap karyawan mendambakan promosi karena dipandang sebagai penghargaan atas keberhasilan seseorang menunjukkan prestasi kerja yang tinggi dalam menunaikan kewajiban dalam pekerjaannya dan jabatan yang dipangkunya sekarang, sekaligus sebagai pengakuan akan kemampuan dan potensi yang bersangkutan untuk menduduki posisi yang lebih tinggi dalam organisasi.

2. Transfer.

Dalam penempatan, alih tugas atau transfer dapat mengambil salah satu dari 2 (dua) bentuk, yaitu : 1) Penempatan seseorang pada tugas baru dengan tanggung jawab, hierarki jabatan dan penghasilan yang relatif sama dengan status yang sama. 2) Alih tempat, jika cara ini yang ditempuh berarti seorang pekerja melakukan pekerjaan yang sama atau sejenis, penghasilan tidak berubah dan tanggung jawabnya relatif sama.

3. Demosi

Adalah bahwa seseorang karena berbagai pertimbangan, mengalami penurunan pangkat atau jabatan dan penghasilan serta tanggung jawab yang semakin kecil. Dapat dikatakan bahwa tidak ada seorang karyawan pun yang senang mengalami ini.

Menurut

(2017:34)Spesifikasi pekerjaan meliputi :

Hasibuan

a) Tingkat pendidikan dan pekerja.

b) Jenis kelamin pekerja.

c) Keadaan fisik pekerja.

d) Pengetahuan dan kecakapan pekerja.

e) Batas umur pekerja.

f) Nikah atau belum

g) Minat pekerja

h) Emosi dan temperamen pekerja.

i) Pengalaman pekerja.

Sedangkan menurut Hanggraeni (2012:32) spesifikasi jabatan itu meliputi :

a) Keahlian.

b) Kecakapan.

c) Tingkat pendidikan.

d) Kemampuan fisik. 
e) Pengalaman.

Dari pendapat para ahli tersebut diatas diketahui bahwa penempatan karyawan ditentukan oleh pendidikan, diantaranya relevansi terhadap pekerjaan yang diembannya, sebab penempatan seseorang pada suatu jabatan tanpa didasarkan dengan riwayat pendidikan maka penempatan tersebut tidak akan optimal, bahkan akan mengurangi prestasi kerja karyawan itu sendiri.

Berdasarkan syarat-syarat yang telah ditetapkan, maka pemimpin perusahaan harus melakukan evaluasi dalam penempatan karyawan yang baik. Penempatan tersebut bertujuan untuk mengetahui siapa yang pantas dan berhak untuk menempati atau menduduki posisi jabatan tertentu.

Menurut

Hanggraeni (2012:78)Penempatan adalah proses penugasan atau penugasan kembali pekerja untuk mengerjakan suatu pekerjaan atau menempati posisi baru di dalam perusahaan.

Dari kutipan tersebut diatas, jelas bahwa untuk memilih karyawan yang akan memduduki jabatan, harus menempatkan seorang karyawan pada suatu posisi atau jabatan tertentu yang dianggap pas untuk dirinya.

Menurut pengamatan yang penulis lakukan, sistem penempatan karyawan yang diterapkan pada PT. Exelcomindo Engineering Indonesia Sumateramasih kurang baik. Hal ini dapat dilihat dari adanya penempatan karyawan yang tidak sesuai dengan skill dan riwayat pendidikan, keadaan ini dapat menyebabkan kurang efektifnya kegiatan perusahaan dan pada akhirnya akan menghambat jalannya operasi perusahaan dalam mencapai tujuan perusahaan.

Menghadapi masalah ini pimpinan perusahaan hendaknya merubah sistem penempatan karyawan dengan cara menempatkan karyawan pada suatu jabatan sesuai dengan kemampuan dan keterampilannya. Dengan demikian tugas para karyawan akan menjadi lancar dan kesalahan atau kerusakan akan dapat diperkecil, dan akhirnya dapat meningkatkan prestasi kerja para karyawan itu sendiri.

\section{Lingkungan Kerja}

Selain masalah sistem penempatan karyawan yang kurang baik PT. Exelcomindo Engineering Indonesia Sumaterajuga mengalami masalah terhadap lingkungan kerja yang kurang mendukung, adapun masalah yang dimaksud adalah mengenai sarana dan prasarana. Seperti kita ketahui bahwa sarana dan prasaran dalam suatu perusahaan merupakan suatu hal yang sangat penting dan vital sekali terutama dalam rangka peningkatan aktivitas perusahaan.

Lingkungan kerja atau kantor biasanya terdiri atas gedung kantor, perkakas dan tata ruang kantor, serta kondisi fisik, didalam mana karyawan melaksanakan pekerjaan. Menurut Moekijat (2002:11) Dalam pemilihan kantor faktor-faktor penting yang perlu diperhatikan adalah :

1) Letak.

Meliputi hal dekatnya dengan pengangkutan, fasilitas-fasilitas Bank, kantor Pos, rumah makan, pasar, para langganan, dan sebagainya.

2) Kelayakan.

Yang paling penting adalah ukuran luas lantai untuk waktu sekarang dan kemungkinan untuk perluasan dimasa yang akan datang.

3) Pertimbangan Keuangan.

Meliputi biaya modal dan biaya pemeliharaan serta biaya penggantian gedung-gedung yang lama.

4) Faktor-Faktor Fisik. 
Meliputi alat untuk naik turun dirumah yang bertingkat, alat pemanas, penerangan, dan sebagainya.

Banyak perusahaan yang mengabaikan tempat kerja para karyawannya, padahal tempat itu merupakan tempat para karyawan selama seharian, bahkan selama sehari ada yang bekerja selama tujuh jam. Tempat kerja yang kurang menyenangkan akan mempengaruhi semangat kerja karyawan. Jadi seharusnya tempat kerja harus senantiasa diperhatikan agar selalu dalam keadaan yang menyenangkan. Salah satu faktor penting adalah kebersihan. Kebersihan bukan hanya ditujukan pada ruang kantor melainkan juga untuk kamar kecil. Walaupun kamar kecil seakan-akan merupakan masalah yang sepele namun akan dapat membawa pengaruh yang besar, apalagi terhadap para karyawan wanita.

Ventilasi ruangan kerja, penerangan lampu dan kesegaran udara harus pula diperhatikan. Suasana menyegarkan dan menyenangkan biasanya banyak dipengaruhi oleh faktor-faktor seperti itu. Suasana yang pengap dan gelap kurang cocok dipakai sebagai tempat kerja, apalagi bagi karyawan yang memerlukan ketelitian. Tentang pewarnaan ruangan (dinding, peralatan kantor dekorasi dan sebagainya) mempunyai pengaruh tersendiri terhadap kejiwaan para karyawan. Dengan pemilihan warna dan pengaturan dekorasi yang tepat, sebenarnya kita akan membangkitkan semangat kerja para karyawan.

Dalam kenyataannya hal ini kurang mendapat perhatian, banyak para perusahaan yang kurang mengerti hal ini padahal sebenarnya mempunyai pengaruh yang cukup besar. Caba saja anda bayangkan, seekor banteng misalnya, ia akan menjadi marah jika dirangsang dengan warna merah. Dan menurut penyelidikan, konon warna oranye dapat mempengaruhi orang untuk memperbesar nafsu makan. Dan bagi seorang yang menderita penyakit tekanan darah tinggi akan bertambah penyakitnya jika disuruh tinggal diruangan yang serba merah. Sebagai penambah kesegaran suasana tempat kerja, bahkan kalau perlu pihak perusahaan menyediakan kafetaria dan tempat bersantai pada saat karyawan beristirahat siang.

Biasanya perusahaan yang besar yang maju tak akan melupakan hal-hal yang kelihatannya sepele ini. Mereka menyediakan tempat rekreasi ringan yang enak dan tenang, sehingga pada saat istirahat siang para karyawan akan memanfaatkan dengan puas. Akibatnya, setelah masa istirahat berlalu, perasaan mereka akan merasa puas dan semangat kerja pulih kembali.

Tata ruang kantor menunjukan penentuan syarat-syarat ruang dan penggunaan secara terinci dari pada ruang ini untuk memberikan susunan prabot dan perlengkapan yang praktis yang diperlukan untuk melaksanakan pekerjaan kantor. Berdasarkan Akta Dasar Bangunan Kantor-Kantor, TokoToko dan sebagainya Tahun 1963 terdiri dari tiga butir antara lain adalah :

1) Merumuskan apa yang dimaksud dengan kantor

2) Menentukan standar minimum tentang aspek-aspek berikut ini.

a. Kebersihan.

b. Pencegahan adanya terlalu banyak orang.

c. Suhu (temperatur).

d. Ventilasi.

e. Penerangan.

f. Jaminan kesehatan.

g. Bantuan pertama.

h. Fasilitas-fasilitas cucian.

i. Air minum. 
j Akomodasi untuk berpakaian.

k. Tempat untuk untuk pekerja.

I. Fasilitas makan.

m. Tindakan pencegahan kebakaran.

3) Menentukan standar yang tepat mengenai :
a. Temperatur (suhu, drajat panas)
b. Luas ruangan yang minimum bagi pekerjaan.
c. Jaminan kesehatan.
d. Air minum dan sebagainya.

Menurut Moekijat (2002:14) pentingnya tata ruang kantor yang direncanakan dengan baik adalah :

1. Menambah efisiensi

2. Menghemat penggunaan ruang lantai

3. Mempengaruhi semangat kerja karyawan

4. Ada penghematan karena pengawasan yang lebih baik, komunikasi yang lebih sempurna, arus pekerjaan yang lebih lancer.

Menurut pengamatan yang penulis lakukan, lingkungan kerja pada PT. Exelcomindo Engineering Indonesia Sumateramasih kurang mendukung. Hal ini dapat dilihat dari masih kurangnya sarana dan prasarana penunjang operasional perusahaan baik itu alat-alat perkantoran maupun pasilitas sarana lainnya seperti bangunan atau gedung, ruangan yang kurang memadai, kamar kecil serta alat penunjang lainnya, keadaan ini dapat menyebabkan kurang efektifnya kegiatan perusahaan dan pada akhirnya akan menghambat jalannya operasi perusahaan dalam mencapai tujuan perusahaan, dalam hal ini adalah keuntungan atau laba.

Menghadapi masalah ini pimpinan perusahaan hendaknya memperhatikan bahkan menambah sarana dan prasarana yang lebih baik seperti halnya yang telah dipaparkan sebelumnya. Dengan demikian tugas para karyawan akan menjadi mudah, lancar, cepat dan kesalahan atau kerusakan akan dapat diperkecil, dan akhirnya dapat meningkatkan prestasi kerja para karyawan.

\section{Kompensasi}

Masalah kompensasi bukan hanya penting karena merupakan pendorongan utama bagi seseorang untuk bekerja, karena kompensasi yang diberikan oleh Perusahaan kepada tenaga kerja, mempunyai kadar pengaruh yang tinggi terhadap moral, disiplin kerja dan prestasi kerja karyawan, oleh karena itu setiap perusahaan atau organisasi manapun sebaiknya dapat menetapkan kompensasi yang seimbang dengan beban kerja yang diberikan kepada karyawan. Sehingga bukan hanya menjamin terwujutnya tujuan pembinaan tenaga kerja berdaya guna dan berhasil guna yang sebesarbesarnya, lebih dari itu tujuan perusahaan untuk meningkatkan omset, output, produksi dapat ditunjang oleh hal itu. Untuk itu dapat ditempuh dengan cara departemen personalia meningkatkan prestasi kerja karyawan, motivasi dan kepuasan kerja karyawan adalah melalui kompensasi.

Menurut Siswanto (2003: 116) kompensasi adalah imbalan jasa atau balas jasa yang diberikan oleh perusahaan kepada tenaga kerja, karena tenaga kerja tersebut telah memberikan sumbangan tenaga dan pikiran demi kemajuan dan kontinuitas perusahaan dalam rangka mencapai tujuan yang telah ditetapkan, baik tujuan jangka pendek maupun jangka panjang.

$\begin{array}{crr}\text { Menurut } & \text { Hani } & \text { Handoko } \\ \text { (2001:245) kompensasi } & \text { adalah }\end{array}$
pemberian kepada karyawan dengan pembayaran financial sebagai balas jasa untuk pekerjaan yang 
dilaksanakan dan sebagai motivator untuk pelaksanaan kegiatan diwaktu yang akan datang.

Pengertian kompensasi selain dari upah, dapat juga berupa tunjang keluarga, tunjangan kesehatan, pakaian seragam dan sebagainya yang dapat dinilai dengan uang, serta bertendensi diberikan secara tetap.

Dari pengertian kompensasi diatas, maka dapat disimpulkan bahwa kompensasi adalah suatu pemberian sebagai imbalan jasa yang diberikan oleh perusahaan kepada karyawan sebagai balas jasa untuk pekerjan yang telah dilaksanakan dan sebagai motivator untuk pelaksanaan kegiatan diwaktu yang akan datang.

Menurut Hasibuan (2017:121) tujuan-tujuan pemberian kompensasi antara lain sebagai berikut :

a) Ikatan kerja sama

Dengan pemberian kompensasi terjalinlah ikatan kerja sama formal antara majikan/pimpinan dengan karyawan.

b) Kepuasan kerja

Dengan balas jasa, karyawan akan dapat memenuhi kebutuhan-kebutuhan fisik, status sosial dan egostiknya sehingga memperoleh kepuasan kerja dari jabatannya.

c) Pengadaan efektif Jika program kompensasi ditetapkan cukup besar, pengadaan karyawan yang qualified untuk perusahaan akan lebih mudah.

d) Motivasi

Jika balas jasa yang diberikan cukup besar, manajer akan lebih mudah memotivasi bawahannya..

e) Stabilitas Karyawan

Dengan program kompensasi atas prinsip adil dan layak serta eksternal konsistensi yang kompetatif maka stabilitas karyawan lebih terjamin karena turn-over relatif kecil. f) Disiplin

Dengan pemberian balas jasa yang cukup besar maka disiplin karyawan semakin baik. Mereka akan mentatti peraturanperaturan yang berlaku.

g) Pengaruh Serikat Buruh

Dengan program kompensasi yang baik pengaruh serikat buruh dapat dihindarkan dan karyawan akan berkonsentrasi pada pekerjaannya.

h) Pengaruh Pemerintah

Jika program kompensasi sesuai dengan undang-undang perburuhan yang berlaku (seperti batas upah minimum) maka intervensi pemerintah dapat dihindarkan.

Menurut Sunyoto (2015:158) Faktor-faktor yang mempengaruhi sistem kompensasi antara lain:

1) Pendidikan, Pengalaman dan

Tanggungan

Ketiga faktor tersebut mendapatkan perhatian. Bagaimana juga tingkat upah seorang sarjana dari yang belum sarjana harus dibedakan, demikianpun antara yang berpengalaman dengan yang belum berpengalaman. Khalayak umum sudah menganggap suatu keadilan bahwa pegawai yang mempunyai tanggungan keluarga besar mempunyai upah yang lebih besar dari kawan sekerjanya yang mempunyai tanggungan keluarga yang kecil.

2) Kemampuan Perusahaan

Faktor ini dalam merealisasikan keadilan dalam pembayaran upah belum berada dalam proposi yang setepat-tepatnya. Jika perusahaan mengalami keuntungan, para pegawai perusahaan harus turut menikmatinya melalui kenaikan tingkat upah atau pembagian keuntungan dan sebaliknya. 
3) Keadaan Ekonomi

Keadaan ekonomi adalah salah satu faktor penting dalam realisasi keadilan dalam pemberian upah.

4) Kondisi-kondisi pekerjaan

Orang yang bekerja di daerah terpencil atau dilingkungan pekerjaan yang berbahaya harus memperoleh upah yang lebih besar dari pada mereka yang bekerja di daerah yang ada tempat-tempat hiburan atau di lingkungan pekerjaan yang tidak berbahaya.

Menurut pengamatan yang penulis lakukan, lingkungan kerja pada PT. Exelcomindo Engineering Indonesia Sumateramasih kurangnya karyawan yang memperoleh kompensasi baik kompensasi langsung maupun kompensasi tidak langsung.

Menghadapi masalah ini pimpinan perusahaan hendaknya memperhatikan tentang pemberian kompensasi bahkan menambah kompensasi baik yang berupa materi maupun non materi. Dengan demikian para karyawan akan menjadi bergairah atau semangat dalam melaksanakan pekerjaannya, dan akhirnya dapat meningkatkan prestasi kerja para karyawan.

\section{H. Kesimpulan dan Saran \\ 1. Kesimpulan}

Berdasarkan penelitian yang telah dilakukan dapat disimpulkan bahwa faktor-faktor yang mempengaruhi prestasi kerja karyawan pada PT. Exelcomindo Engineering Indonesia Sumateraadalah sebagai berikut:

a) Sistem penempatan karyawan yang kurang baik seperti masih adanya penempatan karyawan yang tidak sesui dengan riwayat pendidikan, dalam hal ini tamatan SMA ditempatkan dibagian lapangan, sedangkan tamatan STM ditempatkan dibagian administrasi.

b) Lingkungan kerja yang kurang mendukung karena masih kurangnya sarana dan prasarana penunjang operasional perusahaan seperti bangunan atau gedung, ruangan yang kurang memadai, kamar kecil serta alat penunjang lainnya diantaranya pendingin udara (AC), Komputer serta alat-alat perkantoran lainnya.

c) Pemberian kompensasi yang masih kurang seperti kompensasi langsung maupun kompensasi tidak langsung. Kompensasi langsung adalah prestasi kerja dan hasil kerja karyawan sedangkan kompensasi tidak langsung adalah pemberian kompensasi yang tidak dikaitkan dengan prestasi kerja karyawan, kompensasi ini juga disebut kompensasi pelengkap.

\section{Saran}

Berdasarkan kesimpulan diatas dapat diajukan beberapa saran antara lain :

a) Dalam masalah penempatan tenaga kerja disarankan agar perusahaan mengevaluasi kembali sebelum menempatkan karyawan pada suatu jabatan, berdasarkan kemampuan dan keterampilan yang dimiliki oleh karyawan tersebut sehingga penempatan itu dapat tepat sasaran.

b) Sebaiknya perusahaan memperhatikan bahkan menambah sarana dan prasarana pendukung yang jauh lebih baik dari sebelumnya dalam proses peningkatan prestasi kerja karyawan.

c) Sebaiknya perusahaan juga memperhatikan tentang masalah kompensasi, karena kompensasi 


mempunyai
sangat pengaruh yang
$\begin{aligned} & \text { peningkatan } \\ & \text { penar prestasi }\end{aligned}$ kerja
karyawan.

\section{DAFTAR PUSTAKA}

Arikunto, $\quad$ Suharsimi. 2013. ProsedurPenelitianSuatuPendeka tanPraktik. EdisiRevisi. Jakarta RenikaCipta.

Hanggraeni, Dewi. 2012. Manajemen Sumber Daya Manusia. Jakarta : LPFE- Universitas Indonesia.

Handoko, Hani. 2001. Manajemen Personalia dan Sumber Daya Manusia. Jakarta : BPFE.

Hasibuan, Malayu SP. 2017. Manajemen Sumber Daya Manusia. Jakarta - PT Bumi Aksara.

Mangkunegara, Anwar Prabu. 2006. Perencanaan dan Pengembangan Manajemen
Sumber Daya Manusia. Jakarta PT. Refika Aditama.

Moekijat. 2002. Manajemen Tenaga Kerja dan Hubungan Kerja. Bandung: Pionir Jaya.

Rivai, Veithzal. 2009. Manajemen Sumber Daya Manusia Untuk Perusahaan. Jakarta: Raja Grafindo Persada

Sanusi, Anwar. 2014. Metodologi Penelitian Bisnis. Jakarta : Salemba Empat.

Siswanto, Bedjo. 2003. Manajemen Tenaga Kerja: Ancaman Dalam Pendayagunaan dan Pengembangan Unsur Tenaga Kerja. Bandung: Sinar Baru.

Sunyoto, Danang. 2015. Manajemen dan Pengembangan Sumber Daya Manusia. Yogyakarta : CAPS. 